\title{
Student and Teacher Opinions on Monitorability of Educational Videos
}

\author{
Fatih Balaman (Corresponding author) \\ Department of Computer Education and Instructional Technology \\ Faculty of Education, Mustafa Kemal University, Antakya, Hatay, Turkey \\ Tel: 90-(326)-245-26-00-5285 E-mail: fatihbalaman2010@gmail.com
}

\author{
Yavuz Bolat
}

Department of Curriculum and Instruction, Faculty of Education

Mustafa Kemal University, Antakya, Hatay, Turkey

Tel: 90-(326)-245-26-00-5347Ｅ-mail: yavuzbolat06@gmail.com

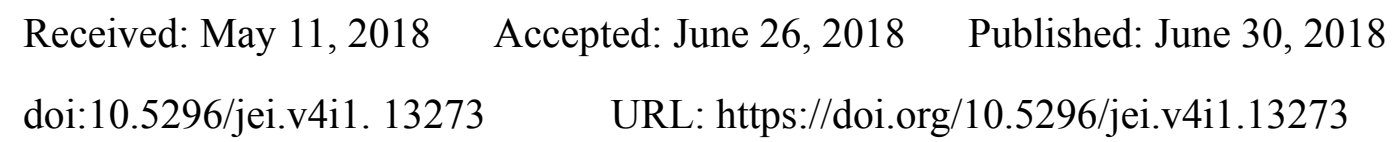

\begin{abstract}
It was aimed at this research to determine the student and teacher opinions relating to the monitorability of educational videos. The study group includes 202 teachers and 486 high school students who are studying totally 688 people at public school in the province center of Hatay in 2017-2018 academic years. The questionnaire form about the monitorability of education videos that was created by the investigators was used as the data collection tool. The answers for the items such as gender, age group, branch, time of the educational video were analyzed for the teachers. The answers for the items like gender, class, time of the educational video were analyzed for the students. Descriptive analysis technique was used in the analysis of the data. Moreover, percentage (\%), frequency (f) values were also utilized. Teacher and students have generally mentioned that the items belong to personal characteristics, duties of video narrator and the specifications of the video are effective on the monitorability of the educational videos. According to another opinion, the time of the video should be between 5 and 10 minutes.
\end{abstract}

Keywords: Educational video, Monitorability of educational video, Education via video, Video developing 


\section{Introduction}

Video has an effect on several domains such as briefing, entertainment, news, advertisement, publicity and education from the time it has taken place in daily life until today. Video has been increasingly used in learning environments by discovering its educational values. Development adventure of a video has its origins in 1950's when is important for the progress of television and television publishing (Marchionini, 2003; Ozan, 2015). Video and educational video process have started by tv broadcasting audits that are performed by Turkish Radio and Television Association (TRT) for Ankara in 1968.

While educators who use technological tools as a significant assistant and supporter of the education try to create a better learning environment for the students, students take advantage of technology for transferring the information and also permanent learning (Bolat, 2016). The necessity for becoming accessible of computer-aided course materials from the internet has emerged from becoming widespread on the internet (Uğur \& Okur, 2016). This circumstance eases educational video to be used in education and training activities. Increasing importance of educational videos has been brought to personal learning areas and mobile devices via electronic environments and internet-based sharing systems. Developing and becoming popular computer technologies have eased the accessibility and quality of the educational videos.

Videos are utilized as a pedagogic tool in education and training environments (Pekdağ, 2010). Educational videos that are used in e-education environments are discussed in two different models as educational video and interactive educational video. The educational video is a type of video that is designed and recorded before; the learner cannot interfere in this sort of videos at the same time. This type of educational videos is monitorable by the learner via television, $\mathrm{CD}$, cassette, computer, smart board, video sharing databases and the mobile devices. Interactive educational videos are a system that creates multimedia by using video and audio factors of TV and computer technologies (Ak, 2014). Moreover, interactive educational videos. Moreover, interactive videos are defined as providing the interaction between human and computer by video images and video broadcasting (Bağış, 2010). There is software such as Zaption, Hapyak, RaptMedia, WireWax, H5P, Snapp App, Captivate that can be used in interactive video production nowadays (Uğur \& Okur, 2016). An increment in the number of video sharing site is observed based on these developments; also these sites are used for education (Yıldırım \& Özmen, 2011). Benefits of the interactive educational videos are as follows,

> It provides learning that is suitable for the principle by doing and experiencing by activating the student;

$>$ It shortens the time of learning of the learner;

> It enables one-to-one learning;

> It minimizes the education costs;

$>$ It helps motivation to increase; 
$>$ It increases the learnability of the subject;

$>$ It enables for repetition and exercises without remaining limited to content topic teaching;

$>$ It gives enough chance to the student for the correct learning;

$>$ It contains parts for evaluating the lessons learned.

White and Nam (2014) find educational video use acceptable for many of the targets of teaching and learning. With reference to them, some of the items that are suitable for video use are as follows,

$>$ Thought development

$>$ Inspiring

$>$ Listening skills

$>$ Estimating

$>$ Discussing

$>$ Interview skills

$>$ Understanding

$>$ Writing

$>$ Information/Explaining

$>$ Storytelling

Using educational video eases the teaching process. Use of technology and technological devices are necessary for easing the teaching. Using educational video is the simplest way of integrating technology into the class. However, some of the teachers stand of using educational video in the class. Therefore, these teachers do not know how the educational video contributes to the class. They also do not know to use and prepare the video (White \& Nam, 2014). This situation restricts the video use. Teachers' abilities relating to the video use should be developed. Videos that are frequently used in information and communication technology can also be used as an effective visual material in education and training activities; accordingly, the memorability of the information increases (Yıldırım \& Özmen, 2011).

The new media that gives extremely advantageous chances for education has paved the way for becoming media an ideal educational material and environment (Ata \& Atik, 2016). Increasing importance of the educational videos has been brought to personal learning areas and mobile devices via electronic environments and internet-based sharing systems. However, the monitorability of videos by the users constitutes a remarkable point. This research aimed to determine the student and teacher opinions relating to the monitorability of the educational videos. There is searched for answers for questions below within the scope of this goal,

(1) What are the demographic attributes of teacher and students participated in the research? 
(2) What are the teacher opinions relating to the monitorability of the educational video?

(3) What are the student opinions relating to the monitorability of the educational video?

\section{Method}

\subsection{Research Model}

This research was conducted in the form of the descriptive survey model. As is known, the survey models include revealing, explaining and evaluating the process of a situation about any subject. Such studies try to understand the problem by describing the event and also detect the current situation within the scope of the research object (Ar1kan, 2013). Descriptive survey model was selected to specify the student and teacher opinions relating to the monitorability of the educational videos.

\subsection{Study Group}

The study group includes 202 teachers and 486 high school students who are studying totally 688 people at public school in the Hatay province center in 2017-2018 academic years.

\subsection{Data Collection Tool}

The questionnaire form relating to the monitorability of the educational videos was used as the data collection tool by the investigators. There are demographic variables and articles about the monitorability of the educational videos in the questionnaire form. Demographic information varies by the student and teachers. There are entirely 18 items and 3 themes as 6 items in the theme of personal characteristics of video narrator; 4 items in the theme of the duties of the video narrator; finally, there are 8 items in the theme of the video specification. A literature review was performed, and an item pool was established relating to the monitorability of the educational videos while the survey items were being prepared. Expert opinions were taken from 3 academicians whose profession is educational sciences and computer education to provide the content validity. Some of the items were eliminated in line with the expert opinions; some of them were reorganized.

\subsection{Analysis of Data}

The answers for the items such as gender, age group, branch, time of the educational video were analyzed for the teachers. The answers for the items like gender, class, time of the educational video were analyzed for the students. Descriptive analysis technique was used in the analysis of the data. Moreover, percentage (\%), frequency (f) values were also utilized.

\section{Findings}

\subsection{Findings Related to Teachers' Demographic Variables}

The teachers in the study group were 114 males $(56.40 \%), 88$ females $(43.60 \%)$ in terms of gender; 38 teachers (18.8\%) aged 20-29 years, 117 teachers $(57.9 \%)$ aged $30-39,42$ teachers (20.8\%) aged 40-49 and 5 teachers $(2.5 \%)$ over 50 years of age. In addition, when it is evaluated in terms of branches, it can be seen that there are teachers from branches which are: information technologies (119), mathematics (12), physics (1), chemistry (4), biology (1), 
culture of religion and knowledge of ethics (5), social sciences (2), physical education (3), English (5), visual arts (4), Turkish (5), science and technology (3), music (4), history (2), classroom teacher (2), philosophy (1) psychological counseling and guidance (2), and the other (27) branches.

There were $31(16.3 \%)$ teachers who think that the time of the educational videos need to be shorter than 5 minutes; 65 teachers $(32.2 \%)$ think that the time of the educational videos need to be between 5-10 minutes; 38 teachers $(18.8 \%)$ think that the time of the educational videos need to be between 11-15 minutes; 28 teachers $(13.9 \%)$ think that the time of the educational videos need to be between 16-30 minutes; finally there are 40 teachers $(19.8 \%)$ think that the time of the educational videos need to be longer than 30 minutes.

\subsection{Findings Related to Demographic Variables of Students}

There were 213 male (43.80\%) and 273 female (56.2\%) high-schoolers in the working group. $234(48.1 \%)$ students study is 9th class; $119(24.5 \%)$ students study in 10th class; 101 (20.8\%) students study in 11 st class; $32(6.6 \%)$ students study in 12 th class.

$34(7 \%)$ of the students think that the time of the educational videos should be shorter than 5 minutes; 184 (37.9\%) of the students think that the time of the educational videos should be between 5-10 minutes; $149(30.7 \%)$ of the students think that the time of the educational videos should be between 11-15 minutes; 70 (14.4\%), of the students, think that the time of the educational videos should be between 16-30 minutes; finally there were $49(10.1 \%)$ students who think that the time of the educational videos should be longer than 30 minutes.

\subsection{Teacher Opinions About Monitorability of Educational Videos}

The teachers mentioned about effectively watching the educational videos by the students that fluently speaking of video narrators is effective by $89.1 \%$, using a simple language is effective by $85.6 \%$, diction is effective by $83.7 \%$, speaking speed is effective by $81.2 \%$. Teachers are few in the number who think that the sincerity $(67.8 \%)$ and gestures and facial expressions $(67.8 \%)$ have less effect on the effectively watching the educational videos. Otherwise, it is understood that the number of teachers who think that the items relating to 'personal characteristics of the narrator' are ineffective is too few. 
Table 1. Teacher Opinions relating to the theme of personal characteristics of the video narrator

\begin{tabular}{|c|c|c|c|c|c|c|}
\hline \multirow{2}{*}{ Personal characteristics of the video narrator in the video } & \multicolumn{2}{|c|}{ Yes } & \multicolumn{2}{|c|}{ Partly } & \multicolumn{2}{|c|}{ No } \\
\hline & $\mathrm{f}$ & $\%$ & $\mathrm{f}$ & $\%$ & $f$ & $\%$ \\
\hline $\begin{array}{l}\text { Being used as a simple language by the narrator is } \\
\text { effective in watching the whole video. }\end{array}$ & 173 & 85.6 & 28 & 13.9 & 1 & 0.5 \\
\hline $\begin{array}{l}\text { The diction of the narrator is effective in watching the } \\
\text { whole video. }\end{array}$ & 169 & 83.7 & 32 & 15.8 & 1 & 0.5 \\
\hline $\begin{array}{l}\text { Speaking speed of the narrator is effective in watching the } \\
\text { whole video. }\end{array}$ & 164 & 81.2 & 37 & 18.3 & 1 & 0.5 \\
\hline $\begin{array}{l}\text { Fluently speaking of the narrator is effective in watching } \\
\text { the whole video. }\end{array}$ & 180 & 89.1 & 20 & 9.9 & 2 & 1 \\
\hline $\begin{array}{l}\text { The sincerity of the narrator is effective in watching the } \\
\text { whole video. }\end{array}$ & 137 & 67.8 & 64 & 31.7 & 1 & 0.5 \\
\hline $\begin{array}{l}\text { Gesture and facial expressions of the narrator are effective } \\
\text { in watching the whole video. }\end{array}$ & 137 & 67.8 & 64 & 31.7 & 1 & 0.5 \\
\hline
\end{tabular}

About watching the educational videos, teachers think that a charismatically start of the narrator for the video is effective by $78.7 \%$; using graphics and animation is effective by $73.8 \%$; mentioning the purpose of the video at the beginning of the video is effective at $71.3 \%$; summarizing the lessons learned is effective by $53 \%$. It is also understood that the number of teachers who think that the items relating to "personal characteristics of the narrator' are ineffective is too few.

Table 2. Teacher opinions relating to the theme called 'duties of the narrator in the video'

\begin{tabular}{|l|l|l|l|l|l|l|}
\hline \multirow{2}{*}{ Duties of Narrator in the video } & \multicolumn{2}{|c|}{ Yes } & \multicolumn{2}{|c|}{ Partly } & \multicolumn{3}{c|}{ No } \\
\cline { 2 - 8 } & $\mathrm{f}$ & $\%$ & $\mathrm{f}$ & $\%$ & $\mathrm{f}$ & $\%$ \\
\hline $\begin{array}{l}\text { A charismatically start of narrator for the video is } \\
\text { effective on watching the whole video. }\end{array}$ & 159 & 78.7 & 42 & 20.8 & 1 & 0.5 \\
\hline $\begin{array}{l}\text { Being mentioned the purpose of the video by the } \\
\text { narrator at the beginning of the video is effective on } \\
\text { watching the whole video. }\end{array}$ & 144 & 71.3 & 55 & 27.2 & 3 & 1.5 \\
\hline $\begin{array}{l}\text { Being summarized the lessons learned by the narrator } \\
\text { at the end of the video is effective on watching the } \\
\text { whole video. }\end{array}$ & 107 & 53 & 93 & 46 & 2 & 1 \\
\hline $\begin{array}{l}\text { Using animation and graphics in the video is effective } \\
\text { on watching the whole video. }\end{array}$ & 149 & 73.8 & 51 & 25.2 & 2 & 1 \\
\hline
\end{tabular}


With reference to the teachers, the effect of voice quality $(89.1 \%)$, quality of contents $(88.1 \%)$, image quality $(84.2 \%)$, currentness of the content $(80.2 \%)$ is high. Again, according to the teachers, the effect of using intro at the beginning of the video $(32.7 \%)$, being the title remarkable $(55 \%)$ is low. It is also understood that the number of teachers who think that the items relating to 'video specifications' are ineffective is too few.

Table 3. Teacher opinions relating to the theme called 'video specifications'

\begin{tabular}{|l|l|l|l|l|l|l|}
\hline \multirow{2}{*}{ Video Specifications } & \multicolumn{2}{|c|}{ Yes } & \multicolumn{2}{|c|}{ Partly } & \multicolumn{3}{c|}{ No } \\
\cline { 2 - 8 } & $\mathrm{f}$ & $\%$ & $\mathrm{f}$ & $\%$ & $\mathrm{f}$ & $\%$ \\
\hline $\begin{array}{l}\text { Video quality (resolution) is effective on watching } \\
\text { the whole video. }\end{array}$ & 170 & 84.2 & 31 & 15.3 & 1 & 0.5 \\
\hline $\begin{array}{l}\text { Brightness of colors (contrast) is effective on } \\
\text { watching the whole video. }\end{array}$ & 139 & 68.8 & 61 & 30.2 & 2 & 1 \\
\hline $\begin{array}{l}\text { Voice quality (sizzle, etc.) is effective in watching } \\
\text { the whole video. }\end{array}$ & 180 & 89.1 & 20 & 9.9 & 2 & 1 \\
\hline $\begin{array}{l}\text { Using intro at the beginning of the video is effective } \\
\text { on watching the whole video. }\end{array}$ & 66 & 32.7 & 133 & 65.8 & 3 & 1.5 \\
\hline $\begin{array}{l}\text { Being the title remarkable is effective on watching } \\
\text { the whole video. }\end{array}$ & 111 & 55 & 90 & 44.6 & 1 & 0.5 \\
\hline $\begin{array}{l}\text { Harmonizing the title and content with each other is } \\
\text { effective on watching the whole video. }\end{array}$ & 157 & 77.7 & 43 & 21.3 & 2 & 1 \\
\hline $\begin{array}{l}\text { Quality of the content is effective in watching the } \\
\text { whole video. }\end{array}$ & 178 & 88.1 & 23 & 11.4 & 1 & 0.5 \\
\hline $\begin{array}{l}\text { Being the content topical is effective on watching } \\
\text { the whole video. }\end{array}$ & 162 & 80.2 & 37 & 18.3 & 3 & 1.5 \\
\hline
\end{tabular}

\subsection{Student Opinions Relating to the Monitorability of Educational Video}

As is seen above, students mentioned about the educational videos that fluently speaking of the narrator is effective by $82.1 \%$; diction is effective by $73.7 \%$; using a simple language is effective by $73 \%$; sincerity is effective by $71.2 \%$. Again, with reference to the same students, speaking speed (59.5\%) and gestures and facial expressions (59.7\%) have less effect on the same issue. Otherwise, the students expressed that gestures and facial expressions $(13.6 \%)$ of the narrator and speaking speed $(8.8 \%)$ of the narrator have no effect on the monitorability of the video. 
Table 4. Student opinions on the personal characteristics of the narrator in video

\begin{tabular}{|l|c|c|c|c|c|c|}
\hline \multirow{2}{*}{ Personal Characteristics of the Narrator in the Video } & \multicolumn{2}{|c|}{ Yes } & \multicolumn{2}{|c|}{ Partly } & \multicolumn{3}{c|}{ No } \\
\cline { 2 - 8 } & $\mathrm{f}$ & $\%$ & $\mathrm{f}$ & $\%$ & $\mathrm{f}$ & $\%$ \\
\hline $\begin{array}{l}\text { Being used as a simple language by the narrator is } \\
\text { effective in watching the whole video. }\end{array}$ & 355 & 73 & 105 & 21.6 & 26 & 5.3 \\
\hline $\begin{array}{l}\text { The diction of the narrator is effective in watching the } \\
\text { whole video. }\end{array}$ & 358 & 73.7 & 108 & 22.2 & 20 & 4.1 \\
\hline $\begin{array}{l}\text { Speaking speed of the narrator is effective in } \\
\text { watching the whole video. }\end{array}$ & 298 & 59.5 & 154 & 31.7 & 43 & 8.8 \\
\hline $\begin{array}{l}\text { Fluently speaking of the narrator is effective in } \\
\text { watching the whole video. }\end{array}$ & 399 & 82.1 & 69 & 14.2 & 18 & 3.7 \\
\hline $\begin{array}{l}\text { The sincerity of the narrator is effective in watching } \\
\text { the whole video. }\end{array}$ & 346 & 71.2 & 103 & 21.2 & 37 & 7.6 \\
\hline $\begin{array}{l}\text { Gesture and facial expressions of the narrator are } \\
\text { effective in watching the whole video. }\end{array}$ & 261 & 53.7 & 159 & 32.7 & 66 & 13.6 \\
\hline
\end{tabular}

While the students accept that a charismatically start of narrator for the video is effective at $71 \%$ and using animation and graphics in video is effective by $64 \%$; a few numbers of students think that being summarized the lessons learned $(12.6 \%)$, being mentioned the purpose of the video $(9.5 \%)$ have no effect on the monitorability of the video.

Table 5. Student opinions relating to the theme called 'duties of the narrator in the video'

\begin{tabular}{|l|l|l|l|l|l|l|}
\hline \multirow{2}{*}{ Duties of the narrator in the video } & \multicolumn{2}{|c|}{ Yes } & \multicolumn{2}{|c|}{ Partly } & \multicolumn{3}{c|}{ No } \\
\cline { 2 - 9 } & $\mathrm{f}$ & $\%$ & $\mathrm{f}$ & $\%$ & $\mathrm{f}$ & $\%$ \\
\hline $\begin{array}{l}\text { A charismatically start of narrator for the video is } \\
\text { effective on watching the whole video. }\end{array}$ & 345 & 71 & 99 & 20.4 & 42 & 8.6 \\
\hline $\begin{array}{l}\text { Being mentioned the purpose of the video by the } \\
\text { narrator at the beginning of the video is effective on } \\
\text { watching the whole video. }\end{array}$ & 295 & 60.7 & 145 & 29.8 & 46 & 9.5 \\
\hline $\begin{array}{l}\text { Being summarized the lessons learned by the narrator } \\
\text { at the end of the video is effective on watching the } \\
\text { whole video. }\end{array}$ & 270 & 55.6 & 155 & 31.9 & 61 & 12.6 \\
\hline $\begin{array}{l}\text { Using animation and graphics in the video is effective } \\
\text { on watching the whole video. }\end{array}$ & 311 & 64 & 133 & 27.4 & 42 & 8.6 \\
\hline
\end{tabular}

According to the expressions of students, while the voice quality $(82.7 \%)$, video quality 
(78.6\%), specification of the content (78.4\%), harmony of title and content $(76.3 \%)$ have effect on the monitorability of the educational videos; using intro at the beginning of the video (40.9\%), being the title remarkable (55.8\%) has less effect on the same issue. Moreover, 122 of the students mentioned that using intro at the beginning of the video $(25.1 \%)$ has no effect on the monitorability of the educational videos. Finally, 63 of them expressed that being the title remarkable $(13 \%)$ has no effect on the same issue mentioned.

Tablo 6. Student opinions relating to the theme called 'video specifications'

\begin{tabular}{|l|l|l|l|l|l|l|}
\hline \multirow{2}{*}{ Video Specifications } & \multicolumn{2}{|c|}{ Yes } & \multicolumn{2}{|c|}{ Partly } & \multicolumn{3}{c|}{ No } \\
\cline { 2 - 8 } & $\mathrm{f}$ & $\%$ & $\mathrm{f}$ & $\%$ & $\mathrm{f}$ & $\%$ \\
\hline $\begin{array}{l}\text { Video quality (resolution) is effective on watching the } \\
\text { whole video. }\end{array}$ & 382 & 78.6 & 87 & 17.9 & 17 & 3.5 \\
\hline $\begin{array}{l}\text { Brightness of colors (contrast) is effective on } \\
\text { watching the whole video. }\end{array}$ & 341 & 70.2 & 120 & 24.7 & 25 & 5.1 \\
\hline $\begin{array}{l}\text { Voice quality (sizzle, etc.) is effective in watching the } \\
\text { whole video. }\end{array}$ & 402 & 82.7 & 53 & 10.9 & 31 & 6.4 \\
\hline $\begin{array}{l}\text { Using intro at the beginning of the video is effective } \\
\text { on watching the whole video. }\end{array}$ & 199 & 40.9 & 165 & 34 & 122 & 25.1 \\
\hline $\begin{array}{l}\text { Being the title remarkable is effective on watching the } \\
\text { whole video. }\end{array}$ & 271 & 55.8 & 152 & 31.3 & 63 & 13 \\
\hline $\begin{array}{l}\text { Harmonizing the title and content with each other is } \\
\text { effective on watching the whole video. }\end{array}$ & 371 & 76.3 & 89 & 18.3 & 26 & 5.3 \\
\hline $\begin{array}{l}\text { Quality of the content is effective in watching the } \\
\text { whole video. }\end{array}$ & 381 & 78.4 & 86 & 17.7 & 19 & 3.9 \\
\hline $\begin{array}{l}\text { Being the content topical is effective on watching the } \\
\text { whole video. }\end{array}$ & 335 & 68.9 & 104 & 21.4 & 47 & 9.7 \\
\hline
\end{tabular}

\section{Discussion and Conclusion}

This research aimed to determine the student and teacher opinions relating to the monitorability of the educational videos. Entirely 688 people (202 teachers work in the city center of Hatay Province in the 2017-2018 academic year; 486 high-schooler studies in the same period) participated in the research.

It is found when the research results are analyzed that fluently speaking, using a simple language and the diction of the narrator is found as significant for the great majority of both students and teachers. However, gestures and facial expressions and also the speaking speed of the narrator have no effect on the monitorability of the educational video.

With reference to the teacher and students, the best fit for educational video time should be 


\section{Ml Macrothink}

between 5-10 minutes. Information, application, visual and interactive evaluation works relating to the targets of the lesson should be submitted in the educational video.

About the theme called 'the duties of the narrator in the video,' the great majority of student and teachers accept that a charismatically start of narrator for the video and using graphics and animation in the video are important. About the theme called 'video specifications,' the general run of teacher and students mentioned that voice quality, quality of contents, video quality are significant for the monitorability. Donkor (2011) conducted a study and pointed out that using video increases the motivation and interest of the student; the video quality also plays a significant role in the same issue.

It remarkable that many of the students accept using intro at the beginning of the video as ineffective. Also the gestures and facial expressions and summarizing the information that will be learned during the video are ineffective for many of the students. With reference to Ozan (2015), as educational video-active pedagogical approaches increases, the need for developing rapid and qualified content. It is possible to say that meeting this need effectively will increase the monitorability of the educational videos.

It is also attention-grabbing that there are a few teachers who think that any of the items are ineffective based on the answers for the items of 3 themes relating to the monitorability of the educational video. According to Kearney and Treagust (2001), students find the educational videos attractive; using videos in education processed increases the satisfaction level. This circumstance refers that educational videos are accepted as successful by the educators inefficient teaching process.

\section{Suggestions}

Following suggestions are offered about the educational videos and the monitorability of the educational videos:

$>$ Presentation skills of the narrator in the educational video should be organized for the level of the student. It must be remembered that fluently speaking, using a simple language and the diction of the narrator will increase the monitorability of the educational video.

$>$ Another factor that affects the monitorability of the video is the longness of the video in terms of the time. The prominent idea relating to the ideal time is between 5 and 10 minutes. Considering for this time interval will also increase the functionality of the educational video towards the education targets.

$>$ A charismatically start of narrator for the video and using graphics and animation in the video will increase the motivation of watcher and learner. This point should be considered in educational video design.

$>$ There should be given wide coverage to the educational videos and interactive educational videos by considering that teacher and students accept educational videos as a significant education tool. 


\section{References}

Ak, E. (2014). Etkileşimli video nedir? Retrieved April 4, 2017, from https://elifak.wordpress. com/2014/04/04/etkilesimlivideo-nedir

Arıkan, R. (2013). Araştırma yöntemleri ve teknikleri (Geliştirilmiş 2. Basım). Ankara: Nobel Akademik Yayıncılık.

Ata, A., \& Atik, A. (2016). Video-sharing websites as an alternative educational environment: Youtube practices in universities. Social Sciences (NWSASOS), 11(4), 312-325. https://doi.org/10.12739/NWSA.2016.11.4.3C0152

Bağış, A. (2010). Etkileşimli video nedir? Retrieved March 5, 2017, from http://nenedir.com. tr/etkilesimli-video-nedir

Bolat, Y. (2016). The flipped classes and education information network (EIN). Journal of Human Sciences, 13(2), 3373-3388. https://doi.org/10.14687/jhs.v13i2.3952

Donkor, F. (2011). Assessment of learner acceptance and satisfaction with video-based instructional materials for teaching practical skills at a distance. International Review of Research in Open and Distance Learning, 12(5), 74-92. https://doi.org/10.19173/irrodl. v12i5.953

Kearney, M., \& Treagust, D. F. (2001). Constructivism as a referent in the design and development of a computer program using interactive digital video to enhance learning in physics. Australian Journal of Educational Technology, 17(1), 64-79. https://doi.org/ 10.14742/ajet.1773

Marchionini, G. (2003). Video and learning redux: New capabilities for practical use. Educational Technology, 43(2), 36-41.

Ozan, Ö. (2015). e-Öğrenme için eğitsel video geliştirme. AUAd, 1(4), 59-80.

Pekdağ, B. (2010). Kimya Öğreniminde Alternatif Yollar: Animasyon, Simülasyon, Video ve Multimedya ile Öğrenme. Journal of Turkish Science Education, 2(7), 79-110.

Uğur, S., \& Okur, M. R. (2016). Açık ve uzaktan öğrenmede etkileşimli video kullanımı. AUAd, 2(4), 104-126.

White, C., \& Nam, M. (2014). How to use video effectively in the classroom. Canada: CBC Learning.

Yıldırm, N., \& Özmen, B. (2011). Video paylaşım sitelerinin eğitsel amaçl kullanımı. 5th International Computer \& Instructional Technologies Symposium, 22-24 September 2011, Firat University, Elaziğ, Turkey. 


\section{Copyright Disclaimer}

Copyright for this article is retained by the author(s), with first publication rights granted to the journal.

This is an open-access article distributed under the terms and conditions of the Creative Commons Attribution license (http://creativecommons.org/licenses/by/3.0/). 